\title{
WITCHES AND WIVES: FEMALE CRUSADE FOR THE ACQUISITION OF MEANINGFUL ROLES IN JACOBEAN DRAMA
}

Sonia HeRnández Santano

Universidad de Huelva

\section{Abstract}

The crisis of absolutism and the religious tensions in the first decades of $17^{\text {th }}$ century in Europe were felt at the level of social and familial organization. The patriarchal system began to fail and many of the commonplaces concerning the relationship between sexes were brought into question. This gender crisis became one of the most popular subjects for drama, where female characters were endowed with new voices which enabled them to vindicate their posts in the emerging order, risking their reputations of ideal wives or even their lives. Marston's The Tragedy of Sophonisba is an example of the degree of control women were achieving over the familial unit by means of the cunning manipulation of patriarchal commonplaces.

The second half of the 16th century and the first decades of the 17th was a period of social and religious tensions in Europe. The conflict between Protestantism and Catholicism meant a menacing instability in Renaissance thought and private social relationships. 
In the last years of Elizabethan supremacy and during the whole reign of James I, the stability of the English Court began to be threatened by challenges to the existing political regime that were mining the peace of England. The monarch's absolute sovereignty over the nation and his/her authority to dispense laws without the consent of the House of Commons was now beginning to be questioned by the Nobility. The Humanist thrust allowed individual voices to emerge, if not in an overt way, as a subliminal subversion. The whole system of political authority, which for a long period of time had been paralleled by the hierarchical organization of the patriarchal system, was now beginning to shake in its foundations. The first symptom of the conflict was a rebellion by the Earl of Essex in 1601 that was followed by a myriad of clashes between King James and the Parliament. In addition, the peerage, whose power had been considerably diminished by Elizabeth I, represented another cause for the social and political nervousness of the period. James' capricious governing, selling peerages and favouring his closest sympathizers, also contributed to increase the tension among the members of the Court; his attitude developed into a progressive loss of the citizens' trust on his figure as representative of the almighty royal authority.

This crisis in the governing apparatus also affected private family life. The structure of the Elizabethan and Jacobean family unit had for long been considered a microcosmic reproduction of the organization of sovereignty in the kingdom; consequently, both were now suffering from the same illnesses. The stereotype of the "silent woman", which had till now been a relevant element for the consolidation of male dominion, was gradually losing its meaning as society became aware of women's increasing role in the system, just in the same way that the «silent population» realized that the king was not an almighty godly ruler. If James' «spouse», as he usually called England in his political treaty Basilikon Doron, was rebelling against her «husband's» supremacy, family wives were simultaneously breaking the conventions in search of a position in the new organization of society.

This gender crisis became one of the main themes in Elizabethan and Jacobean drama; the plays attempted to counteract its harmful effects on the patriarchal writing of history or to subversively support the new pressing social and familial order. Female characters began to acquire relevant roles in the plots, both as the causing elements of discord and moral chaos and as the victims of the established patriarchy. Among the characters who defied the conventional female role, witches best represented women's menace. Far from the stages, witchcraft had actually become a craze in the whole Europe and a lot of women whose behaviours or ways of living were considered anomalous were being tortured and executed to avoid a threat for the prevailing order. Women 
who had not married or had not conventional domestic habits were considered «types of social nonconformity» (TREVOR-ROPER, 1984: 123) and suffered society's rejection and isolation. But female citizens with a different pattern of behaviour were not the only deservers of the name of witches. It also applied to those who physically lacked the worthiest female attributes such as beauty, gracious femininity, and sex appeal, which were features that granted women their due post in the familial system. This is the case of Elizabeth Sawyer, the main character of The Witch of Edmonton (1658), who, being a social outcast, deeply laments her condition in her first speech of the play:

And why on me? Why should the envious world

Throw all their scandalous malice upon me?

Cause I am poor, deformed and ignorant,

And like a bow buckled and bent together

By some more strong in mischiefs than myself,

Must I for that be made a common sink

For all the filth and rubish of men's tongues

To fall and run into? (2. 1. 1-8)

These women's forced isolation led them to live a loose sexuality, which distanced them even more from the pattern of common wives; their attitudes dangerously approached to the conventional code of male sexual behaviours. In her analysis of the craze of witches, K. Newman (1991: 56-57) quotes Scot's remark that «a witch was typically said to be a 'scold', a 'shrew'; to 'live unquietly with her husband'; to be a 'light woman' or a 'common harlot' -witches were regularly accused of 'sexual misconduct' ». However, these sexually odd women were just a reflection of the internal changes operating in the established order of male-female relationships. Sex was ceasing to be an exclusively male concern. In Elizabethan and Jacobean drama female characters were progressively acquiring sexual voices that allowed them to emerge as subjects in a context in which they had never before existed as active elements. Women's speeches in scenes dealing with sexuality or gender conflicts began to have great significance for «to speak is to possess meaning, to have access to the language which defines, delimits and locates power. To speak is to become a subject» (BELSEY, 1991:191). Female progresses in the role distribution and, consequently, within society provoked a mysoginist reaction in the patriarchal apparatus. Women's sexual feebleness and their tendency to infidelity became topics aimed at counteracting female assumption of a sexual identity. King James I, in Daemonology (1597), a comprehensive description of witchcraft, ascribes it to women's frailty: 
The reason is easy, for as that sex is frailer than man is, so it is easier to be intrapped in these grosse snares of the Devill; as was over well proved to be true, by the Serpent's deceiving of Eva at the beginning, which makes him the homelier with that sexe sensine. (30)

Female usurpation of male values led to a reassertion of the Christian myth of women as the origin of human sin and as the ones who lustfully enticed men to feel sexual desire. Their sexuality became a powerful and dangerous instrument at the eyes of men, who felt their moral virility weakened by the charming effects of female attraction. Therefore, the name of witch widened its social connotations towards the love terrain. Women's influence over men in love affairs was metaphorically paralleled to sorcery. In Mother Sawyer's trial, in The Witch of Edmonton, the victim supports her defence on this conception of female witchcraft:

M. Sawyer. A witch! Who is not?

Hold not that universal name in scorn then.

What are your painted things in princes courts,

Upon whose eyelids lust sits, blowing fires

To burn men's soules in sensual hot desires, Upon whose naked paps a lechers thought

Acts $\sin$ in fouler shapes that can be wrought?

$$
\text { (...) }
$$

Have you not City-Witches who can turn

Their husbands wares, whole standing shops of wares

To sumptous Tables, Gardens of stoln $\sin$ ?

In one year wasting, what scarce twenty win.

Are not these Witches?

Justice. Yes, yes but the law

Casts not an eye on these. $(4.1 .103-108,115-119)$

In Elizabethan and Jacobean drama female desire and sex appeal were commonly treated as direct causes of men's neglect of their social duties and, therefore, of the partial loss of their authority. In his speech after the defeat of his fleet, Antony casts all the blame on Cleopatra's love and refers to it as a harmful charm:

This foul Egyptian hath betrayed me;

My fleet hath yielded to the foe.

$$
\text { (...) }
$$

Triple-turn'd whore! 'tis thou 
Hast sold me to this novice, and by my heart Makes only wars on thee. Bid them all fly; For when I am reveng'd upon my charm, I have done all. Bid them all fly; be gone.

$$
\text { (...) }
$$

Betray'd I am.

O this foul soul of Egypt! this grave charm ...

(Antony and Cleopatra, 4. 10. 23-24, 26-30, 37-38)

In Marston's The Tragedy of Sophonisba, Syphax, one the two Lybian kings who contend both for land and for the same woman, blames love for his failure: «I am disgraced in and by that which hath/No reason -love and woman» (1.1.73-74). By «lack of reason» he refers to women's magic power. Whether courtesan ladies -integrated in the parameters of a patriarchal societyby means of the inspiration of love, or witches with their queer skills, both appear as threats to the whole system of patriarchal authority.

The parallelism between witches and sexually worthy women is symbolized in Marston's play by Erictho's cave and Sophonisba's court. The play deals with the rivalry of the two kings of Lybia, Massinissa and Syphax, concerning both land and Sophonisba's love. As she has chosen the former for a husband, Syphax declares war on his rival, who has to interrupt the ceremonies of the wedding night to attend to martial duties. In his absence, the Cartaginians betray Massinissa and deliver his wife to Syphax, who appeals to the witch Erictho's tricks to achieve arising her sexual desire for him; despite all his attemps, she remains unpolluted till her death.

From the beginning of the play, Sophonisba is presented as an example of virtue; she embodies all the qualities conventionally praised in an Elizabethan lady. In the prologue she is defined as a «female glory,/The wonder of a constancy so fixed/That fate itself might well grow envious» (20-22). The «constancy» praised in these lines is related to the loyalty she shows her husband when she rejects a sexual intercourse with Syphax in Act 3, despite the fact that her desire still remains unquenched since her wedding night. Fidelity to husbands was a precious virtue in women in the patriarchal Elizabethan society. In a period in which masculinity was being deprived of part of its authority by women's progressive acquisition of a social identity, legitimacy in issues of paternity became the only means of safeguarding male power within the bosom of the family. Female sexual awareness was providing women with the right of selecting the authors of their conceptions. They were the only ones who controlled the true authorship of their pregnancies and, therefore, the unique owners of men legitimate abdication of their authority into their own descendents. 
For her faithfulness then, Sophonisba becomes The Wonder of Women, as the alternative title Marston gave the play reads. Her actions make her seem adapted to conventional patterns of patriarchal history. However, there are elements in her discourse that corrupt her representation as the ideal female character. In her first speech, delivered while she is being assisted by her maid for the preparations of the wedding night ceremony, she complains about all the paraphernalia that preceeds the accomplishment of desire:

I wonder, Zanthia, why the custom is

To use such ceremony, such strict shape,

About us women. Forsooth, the bride must steal

Before her lord to bed; and then delays

Long expectations, all against known wishes.

I hate these figures in locution,

These about-phrases forced by ceremony.

We must still seem to fly what we most seek

And hide ourselves from that we fain would find.

Let those that think and speak and do just acts

Know form can give no virtue to their acts

Nor detract vice. (1.2.6-17)

Sophonisba denounces the social constraints that prevent women from expressing their sexual identity; she alludes to the ridiculous convention that obliged them to pretend not having sexual anxieties in order to endow men with the main role in intimate relationships, which meant a control over the whole system of procreation. She vindicates the free expression of female desire and complains about the hypocrisy of form and dissimulation in a society that obliged them to conceal their sexual needs in order to preserve their honour and good reputation. With the acquisition of a sexual voice that reveals the audience her inner anxieties, Massinissa's wife disrupts her previous representation as a model female character. The last three lines of her discourse throw what seems to be a personal challenge to the established society; she is determined to show men, the artificers of social conventions («those that think and speak and do just acts», 15), the wrongness of pretended decorum concerning female sexuality. In fact, her words anticipate her husband's failure as the head of the familial unit.

Zanthia echoes her lady's protests about the conflict between forced appearance and women's inner true anxieties:

'Las, fair princess, those that are strongly formed And truly shaped may naked walk, but we, We things called women, only made for show 
And pleasure, created to bear children

And play at shuttlecock, we imperfect mixtures,

Without respective ceremony used,

And ever complement, alas, what are we?

Take from us formal custom and the courtesies

Which civil fashion hath still used to us,

We fall to all contempt. $O$ women, how much,

How much, are you beholding to ceremony!

(1.2.18-28)

Her speech also reveals female realization of the fact that they were passive instruments for the reassertion of male authority and expresses disagreement with the gender organization of the patriarchal system. The opening discourses mean a bold challenge to the conventional social schemes, which suffer serious alterations in the play due to Sophonisba's and the witch Erictho's exertion of power; they become active endowers of both male authority and shame. On one hand, the former commits suicide to endow Massinisa with a honorable position as a politician and exempts him from his marital obligations, which are a hindrance in his military career; but her heroism reveals his lack of legitimate values. On the other hand, Erictho embodies female revenge on male capricious use of women's sexuality; taking Sophonisba's appearance, she employs Syphax to satisfy her lustful desire and punishes his. At first, she makes him believe that her charms will provide him with sex appeal to attract Sophonisba, but then condemns his taking for granted his right to manipulate female desire. The opening speeches therefore anticipate the female characters' usurpation of the ruling powers, which goes beyond the limits of domestic affairs towards the borders of politics. Massinissa's heroical defense of his lands is only made possible by his wife's renounce of her sexual fulfillment. And to deprive her of her eroticism means to mutilate her genre's identity, to prevent her from fully developing as a character, to cause her, first symbolic and then physical, death. Suicide becomes the only means of avoiding suffering this dismemberment again, it's an attempt to preserve her dignity, in such a way mistreated by male prepotency. But it also reveals her awareness of women's role in men's consolidation of their public authority. Because, throughout the whole play and only in the privacy of her soliloquies, she shows a conscious awareness of being playing the role patriarchy has designed for women; she becomes a metacharacter, fully conscious of the need of representing herself as the chaste wife -understanding chastity not only as faithfulness to husbands but as lack of sexual needs.

The ceremony of the wedding night begins when Massinissa in his night gown enters the chamber preceded by four boys «antiquely attired» (stage di- 
rection, 1. 2) and led by Asdrubal, his father-in-law. The boys draw the curtains, discovering Sophonisba on the bed. All this takes place while the cornets and the organ are played and the boys dance. In their encounter, the grooms pronounce a ritual dialogue praising Hymen, the god of chastity, and reconciling this divinity with sexual desire, an act which is only made possible speaking in terms of marriage. Massinissa highlights the sacredness of love and gives his wife sexual license by the symbolic act of loosening the ribbon that oppresses her waist: «Lo, I unloose thy waist!/ She that is just in love is godlike chaste./ Io to Hymen!» (1.2.40-42). The solemnity of this pomp, which Massinissa performs with great seriousness -his speech is an invocation to several gods-, seems ridicule after having witnessed Sophonisba's opinion about this sort of celebrations, but even more when, in her speech in answer to her husband's, she reiterates her defence of women's right to express their individuality despite the fact that society requires their «silence».

A modest silence, though't be thought

A virgin's beauty and her highest honour; (...)

What I dare think I boldly speak.

After my word my well-bold action rusheth;

In open flame then passion break! (1.2.43-44, 47-49)

Throughout the play her speeches frequently contradict the behaviours required of virtuous women. However, at no moment do they mean a violent direct attempt against the patriarchal institutions, as it happens with Alice Arden in the anonymous Arden of Faversham, who openly speaks against marriage and against the duty of accepting a wedding without love:

Sweet Mosby is the man that hath my heart,

And he [Arden] usurps it, having nought but this-

That I am tied to him by marriage.

Love is a god, and marriage is but words,

And therefore Mosby's title is the best. (1.1.98-102)

In contrast, Sophonisba carefully manages to respect the established margins maintaining a discoursive equilibrium. In this occasion, she justifies her previous expression of desire by making reference to marriage as the divine institution that backs her human desires: «Where virtue prompts, thought, word, act never blusheth" (1.2.50). This subtlety in her speeches is paradoxically what makes them effective in their vindications because, far from provoking the other characters' contempt, which would lead them to place her into 
the social ghetto of witches -Alice Arden is condemned to the bonfire-, it allows her to continue being considered till the end a model of «female glory», as she is described in the prologue (20).

Carthalo's sudden entrance to announce the tragedies at the battlefield interrupts the preliminaries to the sexual intercourse and hinders the consummating of the marriage. Massinissa gives preference to his military duties over his marital compromises and departs to war, leaving her wife lamenting her insatisfaction. She complains about the fatality of some events, public events, that «intrude 'mong beds/ Of soft and private loves» (1.2.155-56). The conflict between the private and the public is one of the main debates in the play and reproduces an extended concern in this historical moment in which women were ceasing to be considered mere instrumental figures in the reassertion of male authority and were beginning to exert an active part in the social apparatus. Women had for centuries been condemned to suffer the clash between private and public life, because when they were allowed to take advantage of education or to make use of literature to express their inner anxieties, their "freedom» was conceived as an alternative to a normal family life. Those women who chose to be educated had to live in celibacy because knowledge was in a woman a sign of unnatural sexuality. M. Weisner (1986: 13) states that by becoming learned, the woman «had penetrated a male preserve, which was only tolerable if she simultaneously rejected the world of women». Education for women was, although with many hinderings, at least an object of consideration; however, politics were a forbidden terrain for them. There existed many laws that excluded women from legal participation. They could not buy or sell properties, nor even make a will. Marston's play reflects this conflict between public and private, because Sophonisba's heroical public behaviour is based on her giving up her sexual identity. At the end, she becomes a heroine for her people, her death leaving her husband free to attend to his war duties and to save their lands from trespassers; she sacrifies her private life in order to obtain consent to exert her public power. But the play is something more than a reflection of the unfair reality of women; it also seems to be a parody of male dominion because in two ocassions it shows a husband who is unable to give sexual satisfaction to her wife or, expressed in the code of a patriarchal discourse, to carry out the act of preservation of his lineage. Massinissa fails to make public and private life compatible, which was an exclusive priviledge of male sex. In contrast, Sophonisba succeeds in doing it, for she becomes a heroine in public as well as in private affairs. In public, because her action means freedom for her people, and in private, because she behaves as the spouse society expected her to be. Male and female roles are therefore blurred in the play. 
Though Sophonisba accepts without reluctance her husband's decission of departing, she does not renounce her desire. When she is left alone, she expresses her frustration and leaves her imagination fly with the image of the lost opportunity.

Though my lord leaves his wife a very maid,

Even this night, instead of my soft arms

Clasping his well-strung limbs with glossful steel,

What's safe to Carthage shall be sweet to me. (1.2.158-161)

Her sexuality arises naked in these words as an act of rebellion; the eroticism of the description of Massinissa's virile legs endows her discourse with an improper-for-women courage that advances her forthcoming double heroism. In her monologues, she acquires a male-like voice, she vindicates the freedom to openly express the same basic needs that men do not refrain from making public. And she evidences her awareness of the social unfairness concerning women when she dares admit that they share with men their anxieties and feelings. But, in spite of her boldness, she is always concerned about not transgressing the limits of decorum and, sistematically after a daring discourse, she adopts a patriarchal mood by means of which she recovers her «virtuous» position. In this scene, she employs two of the main Renaissance topics about female genre: first, she ascribes her desire to the well-known moral frailty of her sex and states her determination not to surrender, despite her unsatisfied instincts, to temptation: «no low appetite/ of my sex' weakness can or shall o'ercome/Due grateful service unto you or virtue» (1.2,175-77); and second, she aknowledges her responsibility for this war, because her not chosing Syphax as a husband has been the cause of his rage. Even when female citizens did not play any part at all in the political organization of power, it was a commonplace in Renaissance drama to place much of the blame for political conflicts on them as a cathartic resource for male responsibility. According to convenience, they were given a role in public life, but always with the connotation of transgression and illegitimacy. Virtuous female characters, as the Countess of Pembroke's Cleopatra, were required to live with a feeling of self-blame for their own existence: «My face too lovely caused my wretched case./My face hath so entrapped, to cast us down,/That for his conquest Caesar may it thank,/Causing that Antonie one army lost...»(2. 194-197). Self-blame is the Egyptian queen's main feeling in this Senecan play originally written by Garnier. As for Sophonisba, she has similar words to express her responsibility: «My choice of love hath given this sudden danger/To yet strong Carthage. 
'Twas I lost the fight» (1. 2. 164-165). And to finish with her long speech, she employs the patriarchal convention of women's inclination to talking too much: «. . . But in vain: my tongue/ Swears I am a woman still. I talk too long» (181-182).

As we have seen, female characters were compelled to artifitially keep their paces along patriarchal conventional paths to conceal their inclination towards some manly feelings such as desire or courage. But this is not an exclusively female problem in Renaissance drama for, in this play, men also suffer from several conflicts in their role assumption. For instance, Massinissa represents male uncertainty in dealing with private and public compromises. Once he is armed for the battle, he also laments his sexual insatisfaction and recreates in his imagination how this night could have been (1. 2. 196-97). He reluctantly renounces all the pleasures of love and tries to persuade himself of the fact that what he is going to do is what would be expected from a honourable prince:

Kisses, loves, dalliance, and what softer joys

The Venus of the pleasing'st ease can minister,

I quit you all. Virtue perforce is vice.

But he that may, yet holds, is manly wise. (1.2. 197-201)

But is he really certain of the advantages of behaving as a monarch? He also seems to be trapped by society's strict parameters. On one hand, to give preference to public duties over sentimental anxieties was one of the main requirements for being an entirely noble man. Those as Shakespeare's Antony, who surrender to female charms and neglect their political compromises for a woman, are accused of effeminacy. That is the reason why Massinissa opts for the path of war. And on the other hand, he is to blame for being unable to fulfil his procreative obligations as the head of a family. In a few words, Massinissa feels oppressed by his having to accomplish private and public duties altogether. In the play, Marston creates situations in which male frailty is shown as evidence of the undeserved social injustice women are victims of. In fact, Sophonisba's and the witch Erictho's behaviours function respectively as a moral lesson of female integrity and as a sort of revenge in the name of womanhood. The grooms' discourses at the moment of their farewell reveal how the ideal patriarchal patterns of masculinity and femininity are at stake and need to be repeatedly reasserted by the characters' self-persuasion.

The Carthaginians' conspiracy against their own monarch aims at regaining Syphax's favour in order to avoid his attacks. One of their strategies is to deliver 
Sophonisba to her husband's enemy because, if a woman caused the conflict, let her be the instrument by which peace could be recovered. In their first encounter, Syphax expresses his desire for her and suggests that he would have no scruples in commiting rape if she did not volunteeer in satisfying his sexual needs. As opposed to Massinissa or Shakespeare's Antony, he appears as the Machiavellian stony ruler who does not let feelings hinder his political carreer: «Dost think he pitieth tears that knows to rule?» (3. 1. 6). The formers' main mistake was to allow their frailties emerge, to become aware of the conflicting points between the man of war and the man in love. Antony was admired for his political skill and his good dealing in wars, but his love for Cleopatra deprived him of these manly features and turned him at the eyes of his soldiers into a charmed fool. Massinissa tries to avoid this fate and opts for the opposite way, which means to neglect his wive's desire. And not only once, but twice, because in the last act, when they are for the second time about to fulfil their marriage duties, his military compromises oblige him to betray her again. He sacrifizes his honour as a husband in order to preserve his honour as a prince. By contrast, Syphax's sexual desire is related to his political aims. To possess Sophonisba means to have control over Carthage. Sex becomes for him a strategy of war and female gender an instrument for power, as his threats of rape suggest: «I'll tack thy head/ To the low earth, whilst strength of two black knaves/ Thy limbs all wide shall strain» (3. 1.9-11). Sophonisba's submission in the sexual intercourse would symbolise the subjection of the lands she represents; her legs are to be opened by force, as the gates of a conquered village, to allow virile power enter into what he considers to be his dominion. Anyway, neither Antony, Massinissa or Syphax succeeds in his attempts to play the correct role.

As a trick to delay the sexual intercourse, Sophonisba makes use of the conventional idea that women's «no» in love obeys to the need of concealing their anxieties. She persuades Syphax of her desire for him and requires his permission for performing a sacrifice in her husband's honour, whom she thinks dead. Her discourse evidences her cunning and her awareness of men's needs in sexual dealings:

I am thy servant now. I needs must love thee, For -O my sex forgive!- I must confess

We not affect protesting feebleness, Entreats, faint blushings, timorous modesty;

We think our lover is but little man, Who is so full of woman. Know, fair prince, Love's strongest arm's not rude; for we still prove, Without some fury there's no ardent love. 
We love our love's impatience of delay;

Our noble sex was only born t'obey

To him that dares command. (3.1.29-39)

Once again, the Carthaginian princess pretends being what she is not: the Renaissance stereotype of the unfearful woman. Adapting her discourse to the patriarchal conception of women she is able to preserve Syphax's self-confidence and to avoid a violent reaction provoked by fear; a fear caused by his realization of a progressive loss of control in terms of gender relationships.

Sophonisba takes advantage of his trust and escapes from Syphax's palace, but she is soon captured in the forest by one of his guards. When he realizes his inability to conquer her, Syphax turns to the witch Erictho's charms. His terrifying description of the witch's physical appearance leads us to an underground world where everything is disgusting and terrifying. He describes her black rites, in which she uses pieces of human corpses and practises aberrant sex with dead bodies: «she bites his gelid lips,/ And sticking her black tongue in his dry throat,/ She breaths dire murmurs» (4. 1. 118-120). Necrophilia and other «lecherous actions of imagined lust» (4.1.155), together with her abhorred look, make her a social outcast. She is Sophonisba's opposite; however, their acts seem to flow along parallel paths.

Erictho prepares a canopy for Syphax and makes him wait for Sophonisba's arrival. While waiting, his excitement is increased by the «infernal music» (stage direction, 4. 1) provided by a viol and a bass lute: «O thou power of sound,/ How thou does melt me!» (4. 1. 200-201). This scene is a parody of the ceremony of the wedding-night, in which the music functioned as an enticer for love. These terrifying sounds are for Syphax as «nuptial hymns» (4.1.209). The parallelism between the human and the supernatural worlds, between Sophonisba's court and Erictho's cave, places both women in the same side of the gender battle.

After the intercourse, Syphax discovers that he has lain with Erictho instead of Sophonisba. The witch's satisfaction of his desire seems to be a revenge for all her gender's repression for she speaks in first person plural:

We, in the pride and heigth of covetous lust, Have wished with woman's greediness to fill Our longing arms with Syphax' well-strung limbs.

$$
\text { (...) }
$$

Now we are full

Of our dear wishes. Thy proud heat well wasted Hath made our limbs grow young. Our love, farewell, Know he that would force love, thus seeks his hell.

(5. 1. 13-15, 18-21) 
Erictho's echo of Sophonisba's remark about his husband's «well-strung limbs» (1.2. 161) evidences the equivalence between both worlds. And she reminds him that, for once, male seminal discharge ("proud heat») has ceased to mean a display of their authority over women and has become an act of redemption of female anxieties. Her speech ends with the formulation of her revenge on Syphax for his daring to think that he could use Sophonisba as a material instrument to satisfy his lust. Erictho is therefore a bold representation of female sexuality and desire; from her outcast position she is free to fulfil women's concealed instincts. Furthermore, Syphax's humiliation becomes a symbol of feminine threat to the patriarchal system. The Lybian prince's attempt to rape Sophonisba has been punished by a female character as a revenge for all women's submission to male tyranny.

In the last act, a direct fight between Massinissa and Syphax takes place. Once more, the Carthaginian princess's virginity, which is the main endower of male legitimate power («hymeneal torch», 5. 2. 79), appears as the central cause of the kings' rivalry. When, finally, Massinissa makes Syphax fall, the grooms meet again with the intention of fulfilling their desire. Unfortunately, their ecstasy is again interrupted by Scipio, Massinissa's Roman ally in the fight against the Carthaginians, who requires him to deliver Sophonisba as a symbol of their triumph over her treacherous people. The Lybian king is now obliged to be faithful to his vow. Both his honour as soldier and as husband are at stake; to save one would mean to ruin the other. Sophonisba's suicide provides the solution for his terrible dilemma.

Her heroic act endows him with the honour he has not been able to achieve by himself. Thus, suicide turns Sophonisba into the head of the familial unit for she becomes a key element in the preservation of the patriarchal values of male honour and women self-sacrifice. To discharge him of the marriage bindings means for Sophonisba to renounce her sexual fulfilment and, therefore, her own identity. She embodies the kind of Stoic heroine allowed by patriarchal parameters, whose life's value is measured in terms of its usefulness for the reassertion of established institutions. The opposite kind of heroism would have been the accomplishment of her sexual needs, which is Alice Arden's fault. The latter does not sacrifice her life to save male honour, but her own value as an individual being. All in all, neither of both is allowed to live. Sophonisba's death becomes the only way for avoiding being dismembered once again, deprived of a portion of her identity, whereas Alice's is a punishment for having achieved heroism in life, for having performed her husband's murder in search of her integrity.

Massinissa himself realices women's relevant role in the consolidation of male authority: 
On thee, loved creature of a deathless fame, Rests all my honour.

$$
\text { (..) }
$$

My grief is here, (Pointing his heart) not here.

(Pointing to Sophonisba's body).

Heave gently then,

Women's right wonder, and, just shame of men.

(5. 1, 53-54, 58-60)

He admits that her behaviour has meant a lesson for male proudness, a shame for men. Sophonisba's death provokes in him a moral grief that symbolizes the agonizing descend of patriarchal social schemes towards disintegration.

\section{REFERENCES}

BELSEY, Catherine (1991): The Subject of Tragedy: difference in Renaissance Drama, London, Routledge.

JAMES I (1597): Daemonology in Form of a Dialogue, facs. ed., Edinburg, Robert Walde.

- (1618): Basilikon Doron, facs. ed., Edinburg, Robert Walde.

MARSTON, John (1986): The Tragedy of Sophonisba in Three Jacobean Witcraft Plays, The Revels Plays, Manchester, Manchester U.P.

Newman, Karen (1991): «Discovering Witches: Sorciographics» in Fashioning Femininity and English Renaissance Drama, Chicago, Chicago U.P.

Rowley, William, Thomas Dekker and John Ford (1986): The Witch of Edmonton in Three Jacobean Witcraft Plays, The Revels Plays, Manchester, Manchester U.P.

ShaKeSPEARE, William (1993): Antony and Cleopatra, London, Routledge.

SIDNEY, Mary (1996): The Tragedie of Antonie in Ceresano, S.P. and M. Wynne-Davies (eds.), Renaissance Drama by Women, London, Routledge.

TREVOR-ROPER, Herbert (1984): The European Witch-Craze of the $16^{\text {th }}$ and $17^{\text {th }}$ Centuries, Harmondsworth, Penguin.

WIESNER, Marion (1986): «Women's Defense of Their Public Role» in Rose, M.B. (ed.) Women in the Middle Ages and the Renaissance, Syracuse, Syracuse U.P. WhITE, Marvin (ed.) (1982) Arden of Faversham, New York, W. Norton. 